\title{
ANALYZING STEP IMPLEMENTATIONS FOR Automated Process Planning
}

\author{
TEICH, T.; MilitZer, J.; KRETZ, D.; JAHN, F. \& UnGER, K.
}

Abstract: The response time to customer requests, next to costs or delivery reliability, in a B2B environment is one key factor for gaining purchase orders. Therefore, the authors develop a new model to assist the process of offer preparation. Besides a detailed cost and time planning, the approach takes a new description of company resources into consideration. This description is assigning features to machines and production techniques. The resulting specification represents the supply of a company, the ability to produce single features.

In the developed approach, the description of the demand is a model created by a $C A D$ System. In regards to the functional description of resources by features only, a requirement is the interoperability of the data format produced by several CAD systems. Taking these two points into account, the authors have chosen STEP (STandard for the Exchange of Product model data) as the most advanced standard. This manuscript will deal with the usability of STEP in the context indicated above.

Key words: computer aided design, standard for the exchange of product model data, process planning, computer aided manufacturing
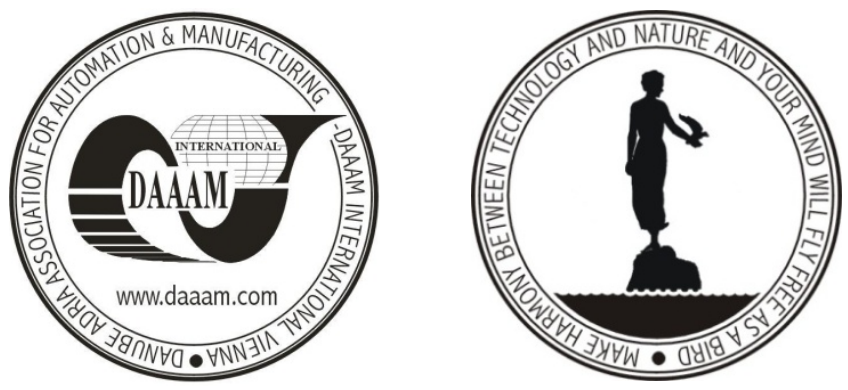

Authors' data: Prof. Dr. rer. pol. habil. Teich, T[obias]; Militzer, J[oerg]; Kretz, D[aniel]; Jahn, F[ranziska]; Unger, K[atja], University of Applied Sciences Zwickau, Dr.-Friedrichs-Ring 2a, 08056, Zwickau, Germany, Daniel.Kretz@fhzwickau.de, Franziska.JJahn@fh-zwickau.de, Tobias.Teich@fh-zwickau.de, Joerg.Militzer@fh-zwickau.de, katja.unger@fh-zwickau.de

This Publication has to be referred as: Teich, T[obias]; Militzer, J[oerg]; Kretz, $\mathrm{D}$ [aniel]; Jahn, F[ranziska] \& Unger, K[atja] (2009). Analyzing STEP Implementations for Automated Process Planning, Chapter 51 in DAAAM International Scientific Book 2009, pp. 513-520, B. Katalinic (Ed.), Published by DAAAM International, ISBN 978-3-901509-69-8, ISSN 1726-9687, Vienna, Austria DOI: $10.2507 /$ daaam.scibook.2009.51 